\title{
ELAC2 Gene
}

National Cancer Institute

\section{Source}

National Cancer Institute. ELAC2 Gene. NCI Thesaurus. Code C113285.

This gene plays a role in the processing of transfer RNA. 